\title{
Restructuring Standards-Based National Education Policies to Support Social Justice in Schools
}

\author{
Linda R. Vogel \\ University of Northern Colorado, Greeley, USA
}

\author{
Brian Annan \\ The University of Aukland, Auckland, New Zealand
}

\begin{abstract}
This paper compared the education policies of the United States (U.S.) and New Zealand as both countries have implemented standards-based educational practices to increase the achievement of all students, particularly those identified as being at risk of low achievement because of poverty or minority ethnicity. While the impetus and justification of policies in both countries have been firmly rooted in calls for greater social justice in providing equitable learning environments for all students, factors such as publicly-reported school ratings based on standardized test performance and the structure of accountability systems often mitigate potential social justice gains and reinforce inequitable social structures within capitalistic economic systems. We explored possible policy changes that would strengthen national policies in the U.S. and New Zealand to promote the enactment of social justice within standards-based education structures. These policy changes include an emphasis on authentic performance-based assessments that are project-based and meaningful to students and public reporting of student growth based on a wider range of assessments and indicators. We also outlined recommendations that address teacher professionalism in developing trustworthy student assessments and evaluating student progress, which could initiate a shift away from the practice of "teaching to the test" that diminishes the motivation of both teachers and students in the learning process.
\end{abstract}

Keywords: standards-based, education policy, social justice, United States (U.S.), New Zealand

\section{Introduction}

Learning standards are intended to ensure that all students, particularly those from low socioeconomic backgrounds and from minority population groups, have the opportunity for an equitable, high-quality education by defining what students should learn (Darling-Hammond, 2010; Gamoran, 2007; Openshaw, 2009). Teachers are guided by these standards to structure student learning and differentiate instruction according to student performance on a variety of assessments in order to help all students demonstrate mastery of the skills and knowledge deemed critical for economic and social well-being. The intention of helping all students, regardless of economic or ethnic background, achieve mastery of critical skills and knowledge for adult economic and social participation is essentially an enactment of social justice, based on the definition of social justice articulated by Bell (1997, p. 3). The adoption of standards-based education policies by a government can also be viewed as a movement toward greater social justice, at least in intent, and is worthy of analysis to gauge

Linda R. Vogel, Ph.D., professor and coordinator, Department of Educational Leadership and Policy Studies, University of Northern Colorado.

Brian Annan, Ph.D., director, Faculty of Education, The University of Aukland. 
both the progress made in equitable educational opportunity and achievement and to highlight the need for policy revisions or new policies to further support the goal of social justice within an education system and society. The United States (U.S.) and New Zealand both have embraced standards-based education since the early 1990s as a means for promoting social justice ${ }^{1}$, as well as economic prosperity (Darling-Hammond, 2010; Openshaw, 2009). While the purposes of implementing standards-based education policies in the two countries have been remarkably similar, the resulting policies are remarkably dissimilar. The following is a descriptive comparison of the education policies and associated political contexts of the U.S. and New Zealand related to the adoption and implementation of standards-based education. The "success" of standards-based education policies can be best defined by the demonstrated learning of students, particularly low socioeconomic and minority students, in the core areas of reading, math, and science. The achievement of U.S. and New Zealand students on the Program for International Student Assessment (PISA) allows for a comparison of overall student achievement as a hallmark of policy "success", although there are limitations to using any international test to compare student achievement (Berliner \& Glass, 2014; Bracey, 2004; Darling-Hammond, 2010; Zhao, 2012). The results of national assessments are discussed to identify student achievement among minority groups that may be indicative of progress made in achieving the goal of social justice in the education systems of the two nations. While educational standards may provide for curricular equity across student groups, it cannot be the only policy lever used to address the achievement gaps in either country. Finally, recommendations for education policy changes will be discussed, drawing on the experiences of both nations, that may further the goal of social justice in the implementation of standards-based educational practices.

\section{Education Policy in the U.S.}

\section{Federal Role in U.S. Education}

The education system of the U.S. was perceived by the founders of the nation as the responsibility of individual states based on the Jeffersonian belief in a small central government and the importance of local control (Guthrie \& Reed, 1991). Thus, the constitution does not "explicitly grant citizens the right to education, nor does it establish a national system of schools" (Guthrie \& Reed, 1991, p. 93). The federal Land Ordinances of 1785 and $1787 \mathrm{did}$, however, prescribe that a section of land was to be surveyed and set aside for a public school in each township in the developing frontier lands (Button \& Provenso, 1983). If sold, the profits were to be invested in public schools based on the belief stated in the 1787 Ordinance that "Religion, morality, and knowledge, being necessary for good government and the happiness of mankind, schools and means of education shall forever be encouraged" (Button \& Provenso, 1983, p. 71). With the passive encouragement of the federal government, states devised various local school systems, building from the post-revolutionary common schools to "high schools" for older students and the formation of city and county school systems in the 1830s (Button \& Provenso, 1983, p. 114).

The provision of federal funds as the incentive for change has been the primary means of federal influence over the education policies of states (Wirt \& Kirst, 1997). The first significant exercise of federal intervention in pubic elementary and secondary schools came in 1958 with the passage of the National Defense Education Act (NDEA) which provided "matching funds as an incentive for local school districts to upgrade instruction in science, mathematics, and foreign language" in response to the successful Soviet launch of the Sputnik satellite

\footnotetext{
1 The working definition of social justice in schools in this paper is both equitable educational opportunities and outcomes for all students.
} 
(Guthrie \& Reed, 1991, p. 101). In 1965, the Elementary and Secondary Education Act (ESEA) provided categorical aid and matching grants, funded demonstration projects, and purchased specific services in order to as a part of President Johnson's War on Poverty (Wirt \& Kirst, 1997, p. 249). Title I of the ESEA made federal assistance available to schools serving students in poverty, defined as qualifying for the free or reduced school lunch program that was started in 1946 in President Truman, and was perhaps the first overt federal attempt to enact social justice in the U.S. education system. In 1976, the Education for All Handicapped Children Act (EHCA, also known as Public Law 94-142) provided funds to school districts that met the federal guidelines for providing services for students with disabilities (Guthrie \& Reed, 1991). EHCA was replaced by the Individuals with Disabilities Act (IDEA) in 1990. The two laws also can be viewed as significant social justice efforts on the part of the U.S. federal government regarding the support and advancement of education for students with disabilities.

Building on the 1964 Civil Rights Act that prohibited discrimination or deliberate segregation based on race, color, gender, religion, or national origin in public schools, the Equal Educational Opportunity Act (EEOA) of 1974 "requires state educational agencies (SEAs) and school districts to take action to overcome language barriers that impede English language learner (ELL) students from participating equally in school districts' educational programs" (U.S. Department of Education, 2013, para. 6). Schools accepting federal funds must provide support to students who are not fluent English speakers, although the type of language acquisition program to be adopted by schools is not dictated by the EEOA. Specific language policies adopted by individual states varying a great deal, from supporting bilingualism to encouraging the use of English only, and often viewed as a social justice issue that is far from reaching an equitable resolution (May, 2008).

\section{Education Crisis and Responses}

In the late 1970s, President Carter established the federal Department of Education (Guthrie \& Reed, 1991). As Ronald Reagan campaigned to lead the U.S., he promised that he would abolish the Department of Education in order to make government more streamlined and cost-efficient at a time that the nation was experiencing "stagflation", a combination of stagnation and inflation. A blue-ribbon panel report commissioned by the Reagan administration, however, actually promoted the growth of the Department of Education rather than its demise. The A Nation at Risk (1983) report blamed the lack of U.S. global economic competitiveness on the abysmal state of public schools (Vogel, 2010). In response, the National Governors Association (NGA), National Business Roundtable, and legislators joined forces to promote education reform in each state (Vogel, 2010; Wirst \& Kirst, 1997). Prominent among these reforms was the adoption of state learning standards and assessments to be used as part of an accountability system to hold educators accountable for student achievement or the lack of it (Vogel, 2010). Danzberger, Kirst, and Usdan (1992) presciently wrote that "These pressures may lead to even more radical reforms at the national level such as the development to national assessments or standards that may well drive the curriculum in our heretofore decentralized educational governance system" (p. 7). The national standards movement was firmly launched by the Clinton administration's Goals 2000 Act, however, no federal funding was linked to the act (Darling-Hammond, 2010).

It was not until the No Child Left Behind (NCLB) reauthorization of ESEA in 2001 that funding and consequences were provided to ensure that assessments of state-developed learning standards were linked to an accountability system for educators and schools, as well as students in varying degree depending upon a state's specific policies. NCLB reinforced "high-stakes testing systems that attach rewards and sanctions to students' 
scores on standardized tests. These include(d) grade retention or promotion, student graduation, merit pay awards or threats of dismissal for teachers and administrators, and closure and reconstitution for schools" (Darling-Hammond, 2010, p. 67). The act specifically held schools accountability for students meeting annual test score targets in various population subgroups defined by race or ethnicity, socioeconomic status, language, and disability. Civil rights advocates supported NCLB as a major breakthrough in promoting social justice in education because:

By flagging differences in student performance by race and class, it shines a spotlight on long-standing inequalities and has triggered attention to the needs of students neglected in many schools. Second, by insisting that all students are entitled to qualified teachers, the law has stimulated some productive recruitment efforts in states where low-income and minority students have experienced a revolving door of inexperienced, untrained teachers. (Darling-Hammond, 2010, p. 67)

The law specified that every child would master a core set of knowledge and skills specified by each state and this mastery would occur at a specific age or grade level (i.e., all 3rd graders would be able to read at the 3rd grade level), as well as narrow and ideally close the "achievement gap" (Vogel, 2012). If schools did not demonstrate progress in increasing student achievement annually for all subgroups, they could be subject to a variety of governmental actions, including reorganization with the dismissal of all current staff or closure.

The language of Title I of the NCLB reauthorization of ESEA clearly spelled out both the social justice goals of the legislation and the means by which such educational equity could be achieved as follows:

The purpose of this title is to ensure that all children have a fair, equal, and significant opportunity to obtain a high-quality education and reach, at a minimum, proficiency on challenging State academic achievement standards and State academic assessments.

This purpose can be accomplished by:

(1) Ensuring that high-quality academic assessments, accountability systems, teacher preparation and training, curriculum, and instructional materials are aligned with challenging State academic standards so that students, teachers, parents, and administrators can measure progress again common expectations for students academic achievement;

(2) Meeting the educational needs of low-achieving children in our Nation's highest poverty schools, limited English proficient children, migratory children, children with disabilities, Indian children, neglected or delinquent children, and young children in need of reading assistance;

(3) Closing the achievement gap between high- and low- performing children, especially the achievement gaps between minority and nonminority, and between disadvantaged children and their more advantaged peers. (Public Law 107-110/107th Congress, pp. 15-16)

Spring (2011) noted that the NCLB expanded Title I in such a way that all children would "be subjected to state standardization of the curriculum and state testing programs" (p. 65) in order to try to close the achievement gap between disadvantaged and minority subgroups. Concerns about the narrowing of the curriculum to "teach to the test"; the reduction or elimination of non-tested subjects including the arts, humanities, social studies, and vocational classes; less engaging and innovative instruction with an emphasis on basic rather than higher order thinking skills; and the reduction or elimination of "recess" or unstructured free time for students have been voiced by several educational experts, as well as other unintended consequences that have developed since NCLB's implementation (Armstrong, 2006; Clinchy, 2007; Kozol, 2005; Ravitch, 2010). Thus, NCLB has had a steady flow of acknowledgements as to the noble intentions of the legislation and the focus it brought to inequities in educational achievement, as well as criticisms of the systems that were 
created in response to NCLB that had negative effects on students and schools ${ }^{2}$.

In addition to highlighting the inequity of student achievement and quality of teachers that the most disadvantaged students were often exposed to, the accountability measures that were generated by NCLB did have some positives effects on educators. Teachers were forced to look at what was being learned, rather than just what was being taught (Vogel, 2010). While many states had gone through several iterations of learning standards, objectives, and outcome statements in the 1990s, NCLB made many educators really seek to understand what learning looked like so that they could prepare students to successfully demonstrate that learning on state assessments. Educators also had to collaborate with each other to an extent unknown in most school settings in order to track student progress on assessments, analyze performance data, and develop classroom responses to increase performance (Vogel, 2010).

Despite the efforts of educators to rise to the challenge of NCLB, Darling-Hammond (2010) explained that:

There is plentiful evidence that-although standards and assessments have been useful in clarifying goals and focusing attention on achievement - tests alone have not improved schools or created educational opportunities without investments in curriculum, teaching, and school supports. Ironically, low-income students of color have been the primary victims of high-stakes testing policies that determine promotion, placements, and graduation, and base school rankings and sanctions on student test scores. (p. 74)

Evidence is presented in Standards-based Reform and the Poverty Gap: Lessons for No Child Left Behind (Gamoran, 2007) to document that poor and minority students have not benefitted from the legislation as had been hoped by NCLB supporters. Furthermore, the economic gap between poor and affluent families and students continues to increase, particularly after the 2009 American recession (Duncan \& Murnane, 2014).

A provision of NCLB outlined new options for parental choice in school selection which was intended to promote school improvement via competition for students in a more market-based context (Clinchy, 2007; Bracey, 2004). Charter schools are publicly funded but exempt from many regulations and requirements of regular public schools. Policies governing and regulating charter schools vary from state to state. Charter schools can, however, refuse admission, require parental involvement as a condition of attendance, and do not have to provide special education or ELL services. Regular public schools cannot refuse admission to any student, cannot require parental participation, and must provide special education and ELL services. The proliferation of charter schools in states since NCLB has in some instances actually produced a resegregation of schools in some states among racial and socioeconomic groups (Ravitch, 2010; Vogel, Whitaker, \& King, 2004).

The Obama administration developed a federal program called "Race to the Top" (RttT) in 2010, which did not supplant NCLB but added incentives to enact policy changes in state education systems. Funds were made available to states to support the development of specific education policies in each state. These policies included increasing teacher quality and effectiveness, increasing school leader quality and effectiveness, increasing student college readiness and job preparation skills, and the adoption of national standards in math and reading. In the third round of funding for RttT in 2012, the following goals for the policies were listed on the Department of Education website:

\footnotetext{
${ }^{2}$ Federal education policies, including NCLB, do not mandate state participation. Rather, states must only abide by the federal regulations of the policy if they accept federal education funds. Utah is the only state that declined ESEA/NCLB funds and therefore does not have to follow the testing and accountability requirements of the legislation.
} 
Adopting standards and assessments that prepare students to succeed in college and the workplace and to compete in the global economy;

Building data systems that measure student growth and success, and inform teachers and principals about how they can improve instruction;

Recruiting, developing, rewarding, and retaining effective teachers and principals, especially where they are needed most; and

Turning around our lowest-achieving schools. (U.S. Department of Education, 2013)

Standards are clearly the lynchpin of current federal education policy in the U.S., with assessments and the data generated by such assessments guiding the development, hiring, evaluation, and termination of teachers and principals, as well as the consequences to schools as outlined by NCLB.

States had developed their own individual learning standards under NCLB. With the emphasis placed on global competitiveness and college readiness, governors from 48 of the 50 states, two territories, and the District of Columbia joined with the Council for Chief State School Offices (CCSSO) to develop the Common Core State Standards (Zhao, 2012). As of the beginning of 2014, "Forty-five states, the District of Columbia, four territories, and the Department of Defense Education Activity have adopted the Common Core State Standards", according to the Common Core Initiative website which is jointly sponsored by the non-governmental organization (NGO) and CCSSO (Common Core Initiative, 2014). According to Zhao (2012), the Common Core State Standards represent the adoption of the first national curriculum in the U.S.. Zhao (2012) posed the question as to why the federal incentivization to adopt nation standards at this point in time materialized and was so widely embraced and cites the answer listed in the Mission Statement of the Common Core Initiative, "to compete successfully in the global economy" (p. 26). The ability to "make test results across schools in different places more comparable, thus making it easier to hold schools and teachers more accountable for learning" also increased the desire of the federal government to see the adoption of a common national curriculum (Zhao, 2012, p. 27). By encouraging the adoption of the Common Core, RttT has increased the centralization of the U.S. education system which has long held local control and the limitation of federal intervention in state affairs as cherished values.

\section{Education Policy in New Zealand}

\section{New Zealand's Centralized Education System}

Public education in New Zealand was originally created as a three-tiered system "consisting of a centralized Department of Education, regional education boards, and local school committees" (Openshaw, 2009 , p. 3). While the original system created in 1877 addressed only primary education, the system was eventually expanded in the 1940s to include secondary schools with the right to free education from the age of five through age 19 with attendance between the ages of six and 16 being compulsory. Secondary schools near to the center of Maori population centers were announced in 1941 in order to make public education more accessible to New Zealand's largest minority group, although these schools replicated the Paheka or New Zealand European structure and curriculum without addressing Maori culture. These changes were seen as part of New Zealand's "most momentous" period of educational change and "rejuvenated the egalitarian tradition in all of its ambiguity: equality of condition and equality of opportunity for all" (Openshaw, 2009, p. 20). In the 1947 McCombs Report, New Zealand was compared to the U.S. in the effort to "make democracy work, though mass education" (Openshaw, 2009, p. 27). 
Concerns over the equity in the quality of education received by New Zealand students across schools emerged in the 1950s in response to government zoning rules which dictated student attendance. According to Openshaw (2009), "The measure of equality allegedly possessed by the original zoning concept was retained and the ideal of the neighborhood school which would provide for a cross-section of the school population within its zone was promoted" (p. 25). Parents could apply for permits to attend schools outside of the attendance zone of their residence and the principals of schools were responsible for issuing these permits, as school space allowed. A system of school certificate examinations and the development of pre-World War II vocational schools served to create a de facto hierarchy of schools, however, so that the policy appeared to offer equality and choice but the most prestigious schools were still attended by the most affluent students.

In 1962, the Currie Report recommended the adoption of a comprehensive model for secondary schools in New Zealand, citing the contemporary Rockefeller Report released in the U.S. that emphasized the economic benefits of educating a majority of citizens to respond to economic challenges and opportunities in the future (Openshaw, 2009). The Currie Report also recommended a "redefinition of official policy as integration rather than assimilation" regarding the education of Maori children (Openshaw, 2009, p. 37). The next decade, however, was to see "a seismic shift from trust in governments to the trust in markets - a reflection, it could be said, of a reverse movement of the Great Depression era" (McKinnon, 2003, p. 282).

\section{Economic Crisis and Education Restructuring}

As Openshaw (2009) described, New Zealand experienced an intellectual change in the 1970s that impacted education policies. A sluggish economy since the 1967 recession coupled with rising demands on the nation's welfare system. In 1978, Franklin, a university professor, attributed the development of a "welfare state" mentality to the secondary school curriculum (Franklin, 1978, p. 133). The newly formed Post-primary Teachers' Association (PPTA) generated a series of books to lay the foundation for both structural and curriculum changes with the recommendation of "a life-adjustment and social meliorist approach to curriculum, not only placing emphasis on student enquiry, contemporary society, and self-respect, but also linking both curriculum and assessment to changes in the wider community, including those taking place in the economy" including participation of New Zealanders in the world market (Openshaw, 2009, p. 49). The final book released in 1972 advocated for a decentralization of schools whereby each school would function as an independent unit, approving its own curriculum to meet the needs of its students. While the PPTA was seen as a radical group, the emergence of the "Moral Right" that cried for a return to educational basics and culture rather than class political alliances gathered momentum for the recommendations of the Picot Report in 1988, Administering for Excellence.

The National Party's election manifesto, also entitled A Nation at Risk to echo the U.S. document released in 1983 of the same name's emphasis on the need for educational reforms to safeguard national economic health, included:

A modular national certificate that would replace earlier vocational qualifications and (place) an emphasis on the maintenance of national standards, coupled with a significant reduction in the role of the state in education to quality control and funding with an emphasis on the rights of consumers rather than providers. (Openshaw, 2009, p. 85)

The government's policy document, Tomorrow's Schools (Lange, 1988), dismantled the "monolithic" Department of Education and created "several new, independent education organizations, such as the Ministry of Education, the Education Review Office, and the New Zealand Qualifications Authority (NZQA)" (Philips, 
2000, p. 1). Schools would be developed, staffed, and run independently by Boards of Trustees (BoTs). Biculturalism was also a prominent aspect of the 1988 reforms, including the development of Maori schools that both recognized the Maori culture to be included in both the structure and content of Maori education and included Maori representation on school governing boards. National guidelines included in Tomorrow's Schools were to be "the means of setting, maintaining, and developing national standards of achievement in education, and (would) be an expression of equity principles, national curriculum objectives, together with codes of conduct for BoTs and principals" (Openshaw, 2009, p. 139).

When the National Party government was elected in 1990, the objectives outlined in the 1983 election manifesto were acted upon. The national government's education policy blueprint, Policy'93, made it clear that education was viewed as "the bridge that links the government's economic and social goals, and that it has the potential to sustain and accelerate economic growth" (Lee \& Hill, 1996, p. 29). In 1993, the New Zealand Curriculum Framework was released and emphasized the goal of a more equitable curriculum, particularly for girls, Maori students, and students with disabilities (New Zealand Ministry of Education, 1993).

Critiques of the sweeping reforms were predictably mixed. Reform supporters pointed to the new parental involvement in schools as a sign of the government's policies' success (Openshaw, 2009). BoT members and education professionals largely worked in harmony, according to Wylie's (1992) annual survey, although the workload of principals, teachers, and BoTs had increased dramatically. More recently, a study conducted by Slowly (2013) illustrated that the demands of school management in the decentralized system required management skills, particularly in market of schools in a competitive market, that detracted from the principal becoming an instructional leader. Although most parents and students reported being satisfied with the schooling that they experienced, "the reforms had widened the gap between rich and poor schools, with many local communities digging deeper into their own resources to provide support for schools" (Baskett, 1998, p. A13).

In 2010, the majority $(2,550)$ of New Zealand's primary and secondary schools operate on an enrollment system based on the school zone of a parent's residence. These schools are typically located in urban areas where there are many schools to select from within a given attendance zone. The remaining schools $(1,850)$ operate on an open enrollment plan where any student can enroll without rejection. Concerns persist that real estate and housing costs in affluent areas serve as a barrier to disadvantaged children attend prestigious, resource-rich schools (Dickison, 2013).

Also in 2010, revised national standards based on a 2000 review of New Zealand's curriculum framework were implemented. As with the New Zealand Curriculum Framework (NZCF) of 1993, it is to be used in all English-medium schools (these include schools where the Maori language is taught as a subject or in which up to $50 \%$ of the curriculum is taught in Maori). The revised framework emphasizes thinking; using language, symbols, and texts; managing self; relating to others; and participating and contributing as core competencies (New Zealand Ministry of Education, 2007). The guiding principles for the development of the new curriculum included high expectations, an emphasis on learning to learn, the biculturalism of the Treaty of Waitangi, cultural diversity, inclusion, community engagement, coherence, and a focus on the future. As with the first iteration of the curriculum framework, the revised curriculum also embraces a constructivist approach to learning to ensure that instruction is suited to and reflects local interests. The National Certificate of Educational Achievement (NCEA) assesses student mastery at the upper secondary grades through performance in each subject area related to the national standards. 


\section{Measures of Policy Success}

The Program of International Student Achievement (PISA) serves as a measure of demonstrated student learning across nations for 15 -year-olds, nearing the end of the required education ${ }^{3}$. Particularly given that the U.S. has cited global competitiveness as the rationale for the most recent national policy initiative, the relative success of the education reforms of the U.S. and New Zealand in terms of overall student achievement can be compared through PISA results over the past decade ${ }^{4}$. As shown in Table 1, the U.S. has consistently scored lower than New Zealand on the PISA, although the gap between the average score in each subject area has decreased since 2003.

Table 1

Comparison of U.S. and New Zealand PISA Scores

\begin{tabular}{|c|c|c|c|c|c|}
\hline & & 2003 & 2006 & 2009 & 2012 \\
\hline \multirow{3}{*}{ Reading } & U.S. & 495 & $\mathrm{NR}^{*}$ & 500 & 498 \\
\hline & New Zealand & 522 & 521 & 521 & 512 \\
\hline & Difference & -27 & - & -21 & -14 \\
\hline \multirow{3}{*}{ Math } & U.S. & 483 & 474 & 487 & 481 \\
\hline & New Zealand & 523 & 522 & 519 & 500 \\
\hline & Difference & -40 & -48 & -32 & -19 \\
\hline \multirow{3}{*}{ Science } & U.S. & 491 & 489 & 502 & 497 \\
\hline & New Zealand & 521 & 530 & 532 & 516 \\
\hline & Difference & -30 & -41 & -30 & -19 \\
\hline
\end{tabular}

Note. ${ }^{*}$ A test printing error invalidated the U.S. results in "Reading" in 2006.

Over this nine-year period, the U.S. reading scores have only varied by five points (495-500), 13 points in math (474-487) and science (489-502), with the highest scores achieved in 2009 in all three subject areas. New Zealand scores have decreased since 2003, with the exception science scores which increased in $2006(+9)$ and $2009(+2)$ and then decreased (-16) in 2012. The variation between the best average score in each subject area for New Zealand was 10 points in reading (512-522), 23 points in math (500-523), and 16 points in science (516-532), with the lowest scores in each area reported for the 2012 PISA.

When taking into account students' socioeconomic differences, such differences were reported as accounting for most of between-school differences in both the U.S. and New Zealand in 2006 (Organization for Economic Cooperation and Development (OECD), 2007). In 2009, socioeconomic background accounted for $16.6 \%$ of the variance of student performance for New Zealand and $16.8 \%$ for the U.S. (OECD, 2010). The 2009 PISA Executive Summary reported that "Across OECD countries, a student from a more socioeconomically advantaged background (among the top seventh) outperforms a student from an average background by 38 score points, or about one year's worth of education, in reading" (OECD, 2010, p. 9). In New Zealand, the gap between advantaged and disadvantaged students was more than 50 score points, and the U.S. gap was 42 score points in 2009.

While the PISA tracks data related to student socioeconomic status, data are not collected regarding

\footnotetext{
3 Student in both the U.S. and New Zealand are required to attend school until they are 16-year-old.

${ }^{4}$ As noted earlier, there are shortcomings in using international assessments to compare student learning outcomes (Baker \& Corcoran, 2012). However, because international comparisons have been used to build support for policy changes in both the U.S. and New Zealand more competitive globally, achievement on the PISA is used in this article as a measure of student learning outcomes.
} 
student race or ethnicity. While there are no directly comparable data available to compare minority student achievement in the U.S. and New Zealand, both countries do publish data regarding minority student achievement, albeit in different contexts, which shows the difference of minority students as compared to majority students. In the U.S., the National Assessment of Educational Progress (NAEP) is given to a large representative sample of 15-year-olds and assesses performance in reading and math. The data do demonstrate a decrease in the achievement gap between Hispanic and White students, as well as between Black and White students. The achievement gap for Hispanic students, the largest minority in the U.S. (16.5\% in 2010 according to the U.S. Census Bureau (2011)), has decreased by only two points in reading and three points in math since 1992, however. The change in the score gap for Black students, the second largest minority group in the U.S. (13.1\% in 2010 according to the U.S. Census Bureau (2011)), has decreased by only eight points since 1980 and was the same in 2007 as it was in 2000 before the adoption of NCLB which emphasized learning standards - and assessments - to decrease the achievement gap between subgroups of students, such as Hispanics and Blacks (see Table 2). Based on these data, education policies that intended to narrow the achievement gap between minorities in the U.S. have been very marginally successful, if one attributes the differences to changes in educational practices.

Table 2

U.S. NAEP Minority Score Gaps for 13-year-olds (1980-2007)

\begin{tabular}{llllll}
\hline & 1992 & 1996 & 2000 & 2003 & 2007 \\
\hline Hispanic reading gap & 27 & 25 & 26 & 27 & 25 \\
Hispanic math gap & 29 & 30 & 31 & 28 & 26 \\
\hline & 1980 & 1992 & 2000 & 2003 & 2007 \\
\hline Black/White reading gap & 32 & 29 & 26 & 27 & 26 \\
Black/White math gap & 41 & 40 & 40 & 35 & 31 \\
\hline
\end{tabular}

New Zealand students do not take one national assessment, but they do accumulate credits related to the national standards in order to recognition of different levels of scholarship according to NCEA levels. Based on the Annual Report on NCEA and New Zealand Scholarship Data and Statistics (NZQA, 2012), the achievement of Maori students, the largest minority group in New Zealand (14.6\% in 2013 according to Statistics New Zealand (2013)), is closer now than in 2008 in literacy but the gap is wider in numeracy over the same time period (NZQA, 2013). In 2012, 3.6\% of Maori students were achieving at the same level as New Zealand European students in literacy (see Table 3).

Table 3

New Zealand NCEA Minority Percentage Gaps for Year 11 Cohort Achieving Level 1

\begin{tabular}{llll}
\hline & 2008 & 2010 & 2012 \\
\hline Maori literacy gap & 14.5 & 14.1 & 10.9 \\
Maori numeracy gap & 12.5 & 11.4 & 14.7 \\
\hline
\end{tabular}

In numeracy, 2.14\% Maori students were achieving at the same level as New Zealand European students. Based on the NCEA data, which represents a very limited time $\operatorname{span}^{5}$, the success of New Zealand's educational reforms appears mixed, again if one attributes the differences to changes in educational practices.

\footnotetext{
${ }^{5}$ NCEA data were available from 2004, however the two subject areas were combined in the reporting of the results and percentage differences were not reported in the same manner as in the most recent NCEA result report.
} 


\section{Policy Implications and Recommendations}

Economic and social justice concerns have spurred reform related to educational standards in both the U.S. and New Zealand. The population size of the two countries, as well as the proportion of minority groups and socioeconomic factors, is very different, however. New Zealand's population in 2011 was 4.4 million (New Zealand Census, 2011) while the U.S. census reported 311.59 million residents (U.S. Census Bureau, 2011). There are some similarities proportionally, however. The two nations had experienced a similar percentage of population growth since 1979 when many of the current reforms first took root, 9.61\% for the U.S. and 10.81\% population growth for New Zealand (New Zealand Census, 2011; U.S. Census Bureau, 2011). In 2011, 36.3\% of the U.S. population was considered a minority with the largest minority group comprised of Hispanics (16.9\%), followed by Blacks (13.1\%) (U.S. Census Bureau, 2011). In New Zealand, Maori population was $14.6 \%$ of the nation's population, followed by Asians (9.2\%) and non-Maori Pacific islanders (6.9\%), for a $30.7 \%$ minority population total in 2011 (New Zealand Census, 2011). In terms of an achievement gap regarding student academic performance, the Maori in New Zealand and Hispanics and Blacks, as well as native Americans to a lesser degree because of minority group percentage (1.2\% of the U.S. population) in the U.S., are the groups identified as performing below the dominant ethnic/racial groups in each country.

Socioeconomics also plays an undeniable role in student performance and is one of the specific targets of efforts to narrow the achievement gap in the U.S. (Gamoran, 2007; Rothenberg, 2007; Rothstein, 2004). According to the National Poverty Center (2010), 15.1\% of Americans lived in poverty in 2010. New Zealand does not have an official poverty measure, however, using low-income thresholds (60\% of median income adjusted for housing costs), 15\% of New Zealanders lived in poverty in 2010 as well (Bellamy, 2011). As mentioned earlier, both the U.S. and New Zealand were noted in the 2006 PISA report as having "relatively strong and steep socioeconomic gradients" in relation to student scores on that international assessment (OECD, 2007, p. 35). The OECD report went on to recommend that such gradients would be best addressed by "socioeconomically targeted policies" (OECD, 2007, p. 35).

Ironically, despite minority and low socioeconomic percentage similarities, the U.S. has responded to equity and economic concerns with education policies that have increasingly centralized education in the 50 states and across 15,000 school districts (Zhao, 2012), while New Zealand has restructured its education system to be highly decentralized in order to promote the efficient use of limited national funding resources (Openshaw, 2009). As discussed earlier, both countries have seen some success in narrowing the achievement gap between minorities, however, the results have been modest rather than dramatic and the gap persists. Furthermore, New Zealand has consistently outperformed the U.S. on the PISA assessments, although the U.S. has increased its scores while New Zealand's scores have declined slightly. Both the U.S. and New Zealand put forth the increased learning and academic achievement of minority students, Blacks and Latinos predominantly in the U.S. and the Maori in New Zealand, as the main reason for the adoption of national education policies since the 1980s (Darling-Hammond, 2010; Openshaw, 2009). Whether using the national measures of student achievement in either country or the PISA international assessment, the issue of social inequity in student outcomes steadfastly remains in both countries. The U.S. policy of a national curriculum based on the Common Core and changes to teacher and principal evaluations to promote effective teaching in response to the federal RttT initiative are just in the process of being implemented by states, thus it is too early to judge the impact of these policies. 
Any policy and large-scale policies in particular will have unintended consequences (Marshall \& Gerstl-Pepin, 2005), and the education policies enacted in the U.S. and New Zealand in the past three decades are no exception. Lubienski, Lee, and Gordon (2013) found that the reorganization of attendance zones in New Zealand limited the access of disadvantaged students to desirable schools. Vogel et al. (2004) found that the growth of charter schools in the U.S. had rolled back many of the gains in desegregating public schools achieved in the early 1980s, with affluent students taking advantage of school choice to a much greater degree than poor or minority students. Increased student retention at grade level, decreased graduation rates, and a deepening of the inequity of resources, both human and material, have been documented in the U.S. since the federal government's most marked involvement in education in 2001 (Darling-Hammond, 2010; Ravitch, 2010). In the U.S., new teacher and principal evaluation systems spurred by the federal RttT policy could result in the reluctance of high quality educators to serve in historically low-performing schools that serve low socioeconomic and high minority students. These unintended consequences can be viewed as lessons to be learned from, however.

The question still remains as to how education policies can be shaped to truly address the social injustice of educational inequity, both of opportunities and outcomes. Educational standards are still a valid means of ensuring that all students are exposed to a curriculum that will prepare them to function as productive citizens, economically and socially (Darling-Hammond, 2010; Vogel, 2010). Standards alone, however, cannot be the sole policy level to address the gap in educational outcomes for minority or poor students. While standards may form the basis of the curriculum in schools across a nation, the quality of teachers and school resources to implement the curriculum with effective pedagogy are critical (Darling-Hammond,2010; Clinchy, 2007). Both quality teachers and adequate school resources must be equitable among schools in order to achieve equitable educational outcomes. Darling-Hammond (2010) explained, "The success of the innovation depends on the capacity of teachers to carry it out, and on the capacity of organizations to implement and continually improve on the reform strategy" (p. 110). She went on to advocate for greater strategic investment in education, both in teacher preparation and in-service professional development, as well as early childhood education to counter socioeconomic background factors, to build this capacity across schools and states. Beck (1997) suggested that an "additional investment of $8 \%$ to $10 \%$ of the gross national product" in the U.S. would be required to accomplish the goal of educating all American students to an acceptable level of competency (as cited in Clinchy, 2007, p. 121). In 2012, however, Baker and Corcoran explained how the inequity of resources among American schools has continued to increase and is likely to continue in this trend, based on an analysis of school funding systems in the U.S.. Given the decentralization and local support of New Zealand schools, additional investment in education might be warranted and effective in addressing inequities there as well (OECD, 2006; Lubienski et al., 2013).

In addition to addressing the teacher and school capacity through additional fiscal investment in education, the curriculum must be presented to students in ways that engage students in the learning process and foster creativity. Formative classroom assessments, high-quality feedback, and constructivist instructional practices contribute to student engagement and increase student learning (R. N. Caine \& G. Caine, 1997; Hattie, 2012; Rogers, Ludington, \& Graham, 1999; Stiggins, 2005). High-stakes accountability systems, such as those in the U.S. at both state and national levels, however, discourage such instructional practices (Zhao, 2012). Standards should form the basis of a common curriculum, and human development principles should guide the development of a formative system to gauge educational outcomes (Armstrong, 2006). Such a system could 
support constant improvement and instructional best practices, similar perhaps to internationally high-achieving Finland where no high-stakes accountability system is in place and teachers are invested in to respond to student learning needs based on current research and professional expertise (Sahlberg, 2010). Perhaps New Zealand's higher performance on the PISA can be attributed to the lack of such a high-stakes accountability system and the curricular emphasis on constructivist instructional practices.

The market-based policies of both New Zealand in the dramatic decentralization of school control and the U.S. growth of charter schools appear to only exacerbate socioeconomic inequity (Darling-Hammond, 2010; Lubienski et al., 2013; Vogel et al., 2004). Thus, pooling resources and functions at an intermediary level of government to address the equity of student access to high-quality educators and resources in all schools might be a more equitable alternative to free-market systems. This would also allow for greater school leader concentration on instructional leadership, the second greatest school variable on student achievement (Louis, Leithwood, Wahlstrom, \& Anderson, 2010). Slowly's (2013) research documents that managerial tasks, such as marketing, have all but eclipsed New Zealand school leaders' focus on instructional leadership, and principals in the U.S. report similar effects in response to increased school competition (MetLife, 2012).

Designing a socially just education system for a nation, regardless of the nation's size, is a formidable and critical task that impacts the prosperity and well-being of citizens in many profound ways. No nation can economically afford to not develop its human capital and, morally, should strive to provide maximal opportunities for the development of human potential. Based on this examination of the education policies of the U.S. and New Zealand in the past 30 years that strove to narrow achievement gaps among disadvantaged students with only a modicum of success, further reform in both countries is necessary to create a socially just education system. The implementation of educational standards is but one piece of policy that has, particularly in the U.S. been expected to enact more socially just, equitable outcomes across student groups. Standards cannot be the only policy lever used to address the achievement gap in either country, however. Greater investment in educator development, formative progress monitoring systems, and a balance of centralized and decentralized organizational structures which promote student-centered instructional practices are all possible alternatives that could increase the equity of outcomes in the education systems of both nations. With such further reform policies, the following statement made by Darling-Hammond as an observation of schools in Singapore might one day be an accurate depiction of schools in the U.S. and New Zealand: "This spirit of creativity and innovation is visible throughout the schools, which are encouraged to engage both students and teachers in experimental and cooperative learning, action research, scientific investigations, entrepreneurial activities and discussion and debate" (Darling-Hammond, 2010, p. 6). If every student is exposed to such learning experiences, the possibility of achieving social justice in educational opportunity and outcome might one day be realized.

\section{References}

Armstrong, T. (2006). The best schools: How human development research should inform educational practice. Alexandria, V.A.: Association of Supervision and Curriculum Development.

Baskett, P. (1998, September 2). Today's schools: Our findings. New Zealand Herald, p. A13.

Baker, B. D., \& Corcoran, C. J. (2012). The stealth inequities of school funding: How state and local school finance systems perpetuate inequitable student spending. Washington, D.C.: Center for American Progress. Retrieved May 28, 2014, from $\mathrm{http} / / / \mathrm{cdn}$.americanprogress.org/wp-content/uploads/2012/09/StealthInequities.pdf 
Bell, L. A. (1997). Theoretical foundations for social justice education. In M. Adams, L. A. Bell, \& P. Griffin (Eds.), Teaching for diversity and social justice: A sourcebook (pp. 3-15). New York, N.Y.: Routledge.

Bellamy, P. (2011). Household incomes, inequality, and poverty (Parliamentary Library Research Paper, New Zealand $\begin{array}{llllll}\text { Parliamentary Library). } & \text { Retrieved } & \text { December } & \text { 8, 2013, }\end{array}$ http://www.parliament.nz/mi-nz/parl-support/research-papers/00PlibCIP181/household-incomes-inequality-and-poverty

Berliner, D. C., \& Glass, G. V. (2014). 50 myths \& lies that threaten American's public schools: The real crisis in education. New York, N.Y.: Teachers College Press.

Bracey, G. (2004). Setting the record straight: Responses to misconceptions about public education in the U.S.. Portsmouth, N.H.: Heinneman.

Button, H. W., \& Provenzo, E. F. (1983). History of education and culture in America. Englewood Cliffs, N.J.: Prentice-Hall.

Caine, R. N., \& Caine, G. (1997). Education on the edge of possibility. Alexandria, V.A.: Association for Supervision and Curriculum Development.

Clinchy, E. (2007). Rescuing the public schools: What it will take to leave no child behind. New York, N.Y.: Teachers College Press.

Common Core Initiative. (2014). Standards in your state. Washington, D.C.: National Governors Association and Consortium of Chief State School Officers. Retrieved from http://www.corestandards.org/in-the-states

Danzberger, J. P., Kirst, M. W., \& Usdan, M. D. (1992). Governing public schools: New times, new requirements. Washington, D.C.: Institute for Educational Leadership.

Darling-Hammond, L. (2010). The flat world and education: How America's commitment to equity will determine our future. New York, N.Y.: Teacher's College Press.

Dickison, M. (2013, January 28). Top schools hire private eye to catch zone cheats. Retrieved January 25, 2014, from http://www.nzherald.co.nz/nz/news/article.cfm?c_id=1\&objectid=10861867

Duncan, G. J., \& Murnane, R. J. (2014). Growing income inequality threatens American education. Retrieved May 28, 2014, from http://www.edweek.org/ew/articles/2014/03/01/kappan_duncanmurnane.html

Franklin, S. H. (1978). Trade, growth, and anxiety. New Zealand beyond the welfare state. Wellington: Methuen.

Gamoran, A. (Ed.) (2007). Standards-based reform and the poverty gap: Lessons for No Child Left Behind. Washington, D.C.: Brookings Institution Press.

Guthrie, J. W., \& Reed, R. J. (1991). Educational administration and policy: Effective leadership for American education (2nd ed.). Boston, M.A.: Allyn \& Bacon.

Hattie, J. (2012). Visible learning for teachers: Maximizing impact on learning. New York, N.Y.: Routledge.

Kozol, J. (2005). The shame of the nation: The restoration of apartheid schooling in America. New York, N.Y.: Crown Publishers.

Lange, D. (1988). Tomorrow's schools: The reform of education administration in New Zealand. Wellington: Government Printer.

Lee, G., \& Hill, D. (1996). Curriculum reform in New Zealand: Outlining the new or restating the familiar? Delta, $48(1), 29$.

Louis, K. S., Leithwood, K., Wahlstrom, K., \& Anderson, S. (2010). Learning from leadership: Investigating the links to improved student learning. University of Minnesota: Center for Applied Research and Educational Improvement.

Lubienski, C., Lee, J., \& Gordon, L. (2013). Self-managing schools and access for disadvantaged students: Organizational behaviour and school admissions. New Zealand Journal of Educational Studies, 48(1), 82-98.

Marshall, C., \& Gerstl-Pepin, C. (2005). Re-framing educational politics for social justice. New York, N.Y.: Pearson.

May, S. (2008). Language and minority rights: Ethnicity, nationalism and the politics of language. Boston, M.A.: Routledge.

McKinnon, M. (2003). Treasury: The New Zealand treasury 1840-2000. Auckland: Auckland University Press.

MetLife. (2012). Challenges for school leadership: A survey of teachers and principals. Retrieved April 23, 2013, from https://www.metlife.com/assets/cao/foundation/MetLife-Teacher-Survey- 2012.pdf

National Poverty Center. (2010). Poverty in the United States: Frequently asked questions. Ann Arbor, M.I.: University of Michigan Gerald R. Ford School of Public Policy. Retrieved December 13, 2013, from http://www.npc.umich.edu/poverty/

New Zealand Census. (2011). Quick stats about New Zealand's population and dwellings. Retrieved November 11, 2013, from http://www.stats.govt.nz/Census/2001-census- data/2001-census-snapshot-downloadable-pdf-files.aspx

New Zealand Ministry of Education. (1993). The New Zealand curriculum framework. Wellington: Learning Media.

New Zealand Ministry of Education. (2007). The New Zealand curriculum. Wellington: Learning Media. 
New Zealand Qualifications Authority (NZQA). (2012). Annual report on NCEA and New Zealand scholarship data and statistics. Wellington: NZQA.

NZQA. (2013). Annual report on NCEA and New Zealand scholarship data and statistics. Wellington: NZQA.

Organization for Economic Cooperation and Development (OECD). (2003). Learning for tomorrow's world: First PISA results 2003. Paris, France: OECD.

OECD. (2007). Executive summary PISA 2006: Science competencies for tomorrow's world. Paris, France: OECD.

OECD. (2010). Executive summary PISA 2009 results: Executive summary. Paris, France: OECD.

OECD. (2013). PISA 2012 snapshot of performance in mathematics, reading and science. Paris, France: OECD.

Openshaw, R. (2009). Reforming New Zealand secondary education: The picot report and the road to radical reform. New York, N.Y.: Palgrave Macmillan.

Philips, D. (2000). Curriculum and assessment policy in New Zealand: Ten years of reform. Educational Review, 52(2), $143-153$.

Public Law 107-110/107th Congress. (2002). An act to close the achievement gap with accountability, flexibility, and choice, so that no child is left behind (pp. 15-16). Washington, D.C.: U.S. Printing Office.

Ravitch, D. (2010). The death and life of the great American school system: How testing and choice are undermining education. New York, N.Y.: Basic Books.

Rogers, S., Ludington, J., \& Graham, S. (1999). Motivation and learning: A teacher's guide to building excitement for learning and igniting the drive for quality. Evergreen, C.O.: Peak Learning Systems, Inc.

Rothenberg, P. S. (2007). Race, class, and gender in the United States (7th ed.). New York, N.Y.: Worth Publishers.

Rothstein, R. (2004). Class and schools: Using social, economic, and educational reform to close the Black-White achievement gap. Washington, D.C.: Economic Policy Institute.

Sahlberg, P. (2010). Finnish lessons: What can be learned from educational change in Finland? New York, N.Y.: Teachers College Press.

Slowly, D. (2013). School self-management in New Zealand: A convenient truth. Journal of Educational Leadership, Policy and Practice, 28(1), 3-13.

Spring, J. (2011). American education. Columbus, O.H.: McGraw-Hill.

Statistics New Zealand. (2013). 2013 census totals by topic-Tables. Retrieved January 4, 2014, from http://www.stats.govt.nz/Census/2013-census/data-tables/total-by-topic.aspx

Stiggins, R. J. (2005). Student-involved assessment FOR learning (4th ed.). Upper Sadle River, N.Y.: Pearson.

U.S. Census Bureau. (2011). US population by year. Retrieved December 15, 2013, from http://www.multpl.com/united-states-population/table

U.S. Census Bureau. (2012). State and county quick facts: USA. Retrieved December 15, 2013, from http://quickfacts.census.gov/qfd/states/00000.html

U.S. Department of Education. (2013). Race to the top fund. Retrieved from http://www2.ed.gov/programs/racetothetop/index.html

Vogel, L. R. (2010). Leading standards-based education reform: Improving implementation of standards to increase student achievement. Lanham, M.D.: Rowman \& Littlefield.

Vogel, L. R. (2012, October 2). U.S. education policy: Where we have been and where we are going. Invitational lecture presented at National Chi Nan University.

Vogel, L. R., Whitaker, K., \& King, R. (2004). Exploring implications of Brown for schools of choice and raising academic standards. Educational Considerations, 32(1). Milwaukee, W.I.: University of Wisconsin at Milwaukee.

Wirt, F. M., \& Kirst, M. W. (1997). The political dynamics of American education. Berkeley, C.A.: McCutchan Publishing Corporation.

Wylie, C. (1992). The impact of tomorrow's schools in primary schools and intermediates: 1991 survey report. Wellington: New Zealand Council For Educational Research.

Zhao, Y. (2012). World class learners: Educating creative and entrepreneurial students. Thousand Oaks, C.A.: Corwin Press. 